\title{
Biocontrol in Australia: Can a carp herpesvirus (CyHV-3) deliver safe and effective ecological restoration?
}

\author{
R. K. Kopf - M. Boutier $\cdot$ C. M. Finlayson $\cdot$ K. Hodges $\cdot$ P. Humphries \\ A. King • R. T. Kingsford - J. Marshall $\cdot$ H. M. McGinness $\cdot$ R. Thresher \\ A. Vanderplasschen
}

Received: 7 September 2018/ Accepted: 13 March 2019

(C) Springer Nature Switzerland AG 2019

\begin{abstract}
The Australian Government is considering Cyprinid herpesvirus 3 (CyHV-3) for biocontrol of invasive common carp (Cyprinus carpio L.). We review the evidence-base for its potential ecological risks, benefits and effectiveness. Lower carp abundance may boost native fish biomass and improve water clarity, but there is little evidence available to suggest that the virus, alone or used in combination with other methods, can deliver effective or safe biocontrol. Further, the virus may already be present in
\end{abstract}

Electronic supplementary material The online version of this article (https://doi.org/10.1007/s10530-019-01967-1) contains supplementary material, which is available to authorized users.

R. K. Kopf $(\varangle)$ · C. M. Finlayson · P. Humphries Institute for Land Water and Society, Charles Sturt University, Albury, NSW 2640, Australia

e-mail: rkopf@csu.edu.au

M. Boutier · A. Vanderplasschen

Department of Parasitic and Infectious Diseases,

University of Liège, Liège 4000, Belgium

\section{K. Hodges · J. Marshall}

Queensland Department of Environment and Science,

Water Planning Ecology, Brisbane, QLD 4001, Australia

\section{A. King}

Research Institute for the Environment and Livelihoods, Charles Darwin University, Darwin, NT 0909, Australia
Australia. Overseas, the virus has caused sporadic and localized mortalities of carp in lakes and rivers, but has generally had no long-term measurable effect on wild carp or native fish populations. The temperature range of disease $\left(18-28^{\circ} \mathrm{C}\right)$, unknown co-factors causing outbreaks, and predictable re-colonization and recruitment boom of immune and virus-resistant carp, following a biocontrol release, remain formidable and unmitigated barriers to success. CyHV-3 infection trials on Australian biota have unexplained high mortality rates of recreationally-important and threatened fishes, and the role of asymptomatic carriers remains uncertain. Finally, Australia has national and international obligations to ensure that there are no

\author{
R. T. Kingsford \\ Centre for Ecosystem Science, School of Biological, Earth \\ and Environmental Sciences, UNSW Sydney, Sydney, \\ NSW 2052, Australia \\ J. Marshall \\ Australian Rivers Institute, Griffith University, Nathan, \\ QLD 4111, Australia \\ H. M. McGinness \\ Commonwealth Scientific and Industrial Research \\ Organisation, Canberra, ACT 2601, Australia \\ R. Thresher \\ SF Tech, 50 Bramble Street, Ridgeway, TAS, Australia \\ C. M. Finlayson \\ IHE Delft, Institute for Water Education, Delft, \\ Netherlands
}


perverse outcomes from biocontrol actions. Despite political pressure, there is no environmental justification to rush the release of this virus. To achieve the Government goals of restoring native biodiversity we advocate that key uncertainties, risks and efficacy barriers first need to be addressed. It is only then that viral biocontrol could be considered a viable tool to complement broader ecological restoration strategies for Australia's waterways.

Keywords Biological control - Cyprinid herpesvirus $3(\mathrm{CyH}-3) \cdot$ Risks $\cdot$ Invasive alien species $\cdot$ River restoration $\cdot$ Ramsar $\cdot$ Murray-Darling Basin

\section{Introduction}

Biocontrol is one of few environmental management actions that can transform ecosystems. Australia has a long history of biocontrol successes, such as the reduction of previously super-abundant prickly pear (Opuntia spp.) by releasing a cactus moth (Cactoblastis cactorum) during the 1930's (Dodd 1936), or the decline of European rabbit (Oryctolagus cuniculus), caused by releases of myxoma virus in the 1950's and rabbit haemorrhagic disease virus in 1996 (Pedler et al. 2016). However, Australia's biodiversity has also been damaged following what with hindsight were reckless biocontrol releases. For example, the introduction of cane toads (Rhinella marina) to control cane beetles (Dermolepida albohirtum and Lepidiota frenchi) and eastern gambusia (Gambusia holbrooki) to control mosquitos, not only failed to reduce pest populations but the biocontrol agents subsequently became environmentally destructive invasive species themselves (Shine 2010; Hinchliffe et al. 2017). These releases were driven in large part by a zealous focus on anecdotal benefits and political expediency, without rigorous testing of their likely effectiveness or risks (Pyke 2008; Turvey 2013). Perverse outcomes often arise from well-intentioned environmental management interventions (Hobbs et al. 2011), and therefore invasive species control decisions should not be assumed safe without a substantial evidence-base (Simberloff and Stiling 1996; Doherty and Ritchie 2017; Kopf et al. 2017).

Cyprinid herpesvirus 3 (CyHV-3), previously referred to as Koi herpesvirus, is being considered as
Australia's next major biocontrol agent. The virus has never been applied as a biocontrol but it is being evaluated as a potential tool to control invasive common carp (Cyprinus carpio L.), hereafter 'carp' (McColl et al. 2016a, b; McColl et al. 2017). The potential release of CyHV-3 is a key focus of Australia's National Carp Control Plan (NCCP 2017) which is a project intended to help restore native biodiversity. As far as we are aware, the potential release of CyHV-3 would represent the first large-scale attempt at viral biocontrol in an aquatic ecosystem. CyHV-3 was first detected in aquaculture operations in Germany, Israel and the United States in the 1990's, subsequently spread to over 33 countries, and caused widespread mortality events of carp in fish farms, and to a much lesser extent in lakes and rivers (Boutier et al. 2015).

Although carp is one of the most widely cultured fish produced for food world-wide, it is also one of the most prolific invasive species (Lowe et al. 2000), often causing ecological changes that adversely affect biodiversity and ecosystem functioning (Koehn 2004; Weber and Brown 2009; Kulhanek et al. 2011; Vilizzi et al. 2015). Originally from the Black, Caspian and Aral Sea basins (Balon 1995), carp was first introduced into Australia for aquaculture in the mid-1800s, but only became abundant and widespread in the wild following floods in the 1970's (Koehn 2004). In 1964 a new genetic strain spread from fish farms, and had expanded to most of the Murray-Darling Basin (MDB) by 1977 (Shearer and Mulley 1978). Carp are now widely distributed in Queensland, New South Wales, Victoria, and South Australia and are also found in two lakes in Tasmania. Carp is currently one of the most prolific freshwater fishes in Australia, and where it occurs it makes-up approximately 60-90\% of all fish biomass (Harris and Gehrke 1997; Koehn 2004; Kopf et al. 2018). In Australia, the effects of carp are ecosystem-dependent, but high densities have been associated with elevated turbidity and pelagic algae (King et al. 1997; Robertson et al. 1997) and declines in macrophytes (Fletcher et al. 1985) and native fish biomass (Kopf et al. 2018).

Here, we provide an independent perspective on the risks, benefits and effectiveness of CyHV-3 as a biocontrol agent for carp in Australian waterways. We address four questions relevant to scientists, managers and policy-makers: (1) Can native species be infected 
by or transmit CyHV-3?; (2) What are the broad ecological risks of unintended and perverse outcomes from biocontrol with CyHV-3?; (3) Is there evidence of CyHV-3 delivering effective control of wild carp populations? and (4) What are the potential ecological restoration benefits of carp control? This is not an exhaustive list of potential benefits, efficacy or safety issues, but provides a synthesis of the epidemiological and ecological evidence-base for considering CyHV-3 as a biocontrol agent. The viability of carp biocontrol, like any natural resource management initiative, ultimately depends on social acceptability and whether benefits exceed costs. Socio-economic and human health issues, such as the cost of a clean-up, effects on drinking water, tourism, infrastructure, food security and aquaculture industries, although important, are not considered here.

\section{Can native species be infected by or transmit CyHV-3?}

Knowledge of the species-specificity of a potential biocontrol agent is fundamental to avoid perverse outcomes for non-target species. Herpesviruses are generally host-specific and host-stable and CyHV-3 is not reported to have caused disease in any species other than carp, koi and related hybrids (Boutier et al. 2015). McColl et al. (2016b) reported on the susceptibility of 22 Australian non-target species to CyHV-3 and concluded there were no clinical signs of disease or molecular evidence of viral infection. However, Australian non-target fish species suffered high rates of mortality in both virus treatments and controls (Fig. 1). Species with unusually high mortality rates in the virus treatments included, but were not limited to, non-native but recreationally important rainbow trout (Oncorhynchus mykiss; 45-100\% mortality) and a native fish, silver perch (Bidyanus bidyanus; $27-46 \%$ mortality). Silver perch are listed as threatened by the Australian Environmental Protection and Biodiversity Conservation Act 1999 (EPBC 1999). For both species, the percent mortality in the controls (no virus present) was less than $10 \%$. High mortalities (up to 91\% in Common Galaxias Galaxias maculatus and Olive perchlet Ambassis agassizii) in the controls of other Australian species tested indicated that laboratory conditions were inadequate for reliable experimentation. Given the unexplained mortalities, we recommend additional susceptibility and transmission trials for non-target fish species (Table 1), focusing especially on taxa that suffered high (e.g. $>20 \%$ ) rates of mortality in controls or treatments (Fig. 1).

Based on existing evidence of herpes virus epidemiology (Boutier et al. 2015) and absence of clinical disease symptoms (McColl et al. 2016b), it is highly unlikely that the CyHV-3 can cause disease in native species. Although CyHV-3 exposure adversely affecting native species is highly improbable, these potentially catastrophic risks and unquestionably high rates of mortality in experiments should not be ignored. Native species may have never been in contact with the virus, and the large geographic area of carp in Australia represents a novel opportunity for virus evolution (Lighten and van Oosterhout 2017).

A related issue of uncertainty in the literature is which species act as asymptomatic carriers or vectors that could carry and transmit a viral infection. Piscivorous waterbirds are potential vectors via physically transporting water or infected fish (Ilouze et al. 2010). Over 29 potential asymptomatic carrier species of fish in nine families, and two species of invertebrates have tested positive for CyHV-3 DNA (Kempter et al. 2012; Boutier et al. 2015; Fabian et al. 2013, 2016; Gaede et al. 2017). Importantly, some of the non-target species which tested positive also effectively transmitted the virus to naïve cohabitant carp (Kempter et al. 2012; Fabian et al. 2013, 2016). Despite claims by McColl et al. (2016b), effective transmissions by non-target species in several independent studies suggests that some non-target species carry and transmit the virus. However, several of these previous trials were performed using highly sensitive 'nested PCR', prone to lab contaminations (OIE 2012), which may have falsely detected viral DNA. McColl et al. (2016b) found no molecular evidence of any non-target Australian species replicating CyHV-3, but did not conduct studies to determine whether nontarget species could effectively transmit the virus. McColl et al. (2016b) used RT-PCR and a qPCR method initially designed by Gilad et al. (2004), which is considered to be one of the international reference methods for testing CyHV-3 (OIE 2012). Research is needed to identify non-target species that may effectively transmit the virus, or act as potential asymptomatic carriers (Table 1). Furthermore, no previous research has evaluated the potential for sub-lethal effects (e.g. compromised immune function, stress, 
Fig. 1 Median percent mortality of non-target species in Australia exposed to CyHV-3 (black-virus treatments), compared to controls (white-no virus present) by McColl et al. (2016b). Values represent the median of bath immersion and injection procedures by McColl et al. (2016b; Table 1). Species denoted (a) are listed as threatened by the Australian Environmental Protection and Biodiversity

Conservation Act 1999 (EPBC 1999) and by the International Union for the Conservation of Nature (IUCN) Red List and species denoted (b) are considered recreationally or commercially important. Statistical comparisons and error bars could not be calculated because replicate exposure trials were either not conducted or not reported for all but one nontarget species (M. peelii). Fish silhouettes highlight species discussed in the text

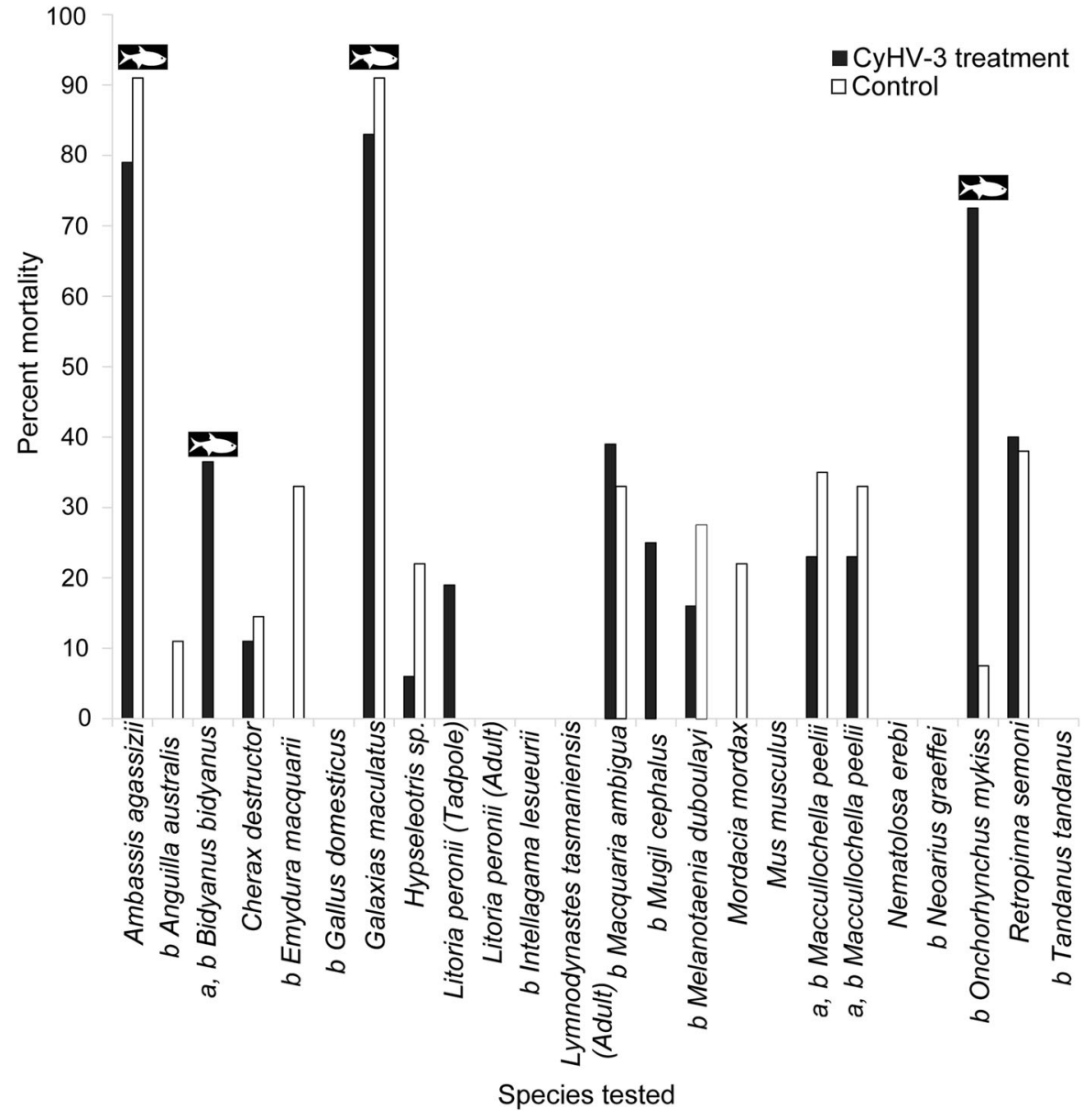

growth, reproduction) of low-level viral infections on potential carriers. Better knowledge of the speciesspecificity of CyHV-3 asymptomatic carriers and transmission is likely to serve the dual purpose of mitigating risks and improving the accuracy of epidemiological models needed to predict the spread of disease.

\section{What are the broad ecological risks of unintended and perverse outcomes from biocontrol with CyHV-3?}

The removal of invasive species requires a wholeecosystem perspective (Zavaleta et al. 2001; Simberloff et al. 2013), with rigorous assessment of the risks of removing widespread and established species from environments (Kopf et al. 2017). Unlike the lowlikelihood lethal or sub-lethal risks of CyHV-3 infection of non-target species (Question 1), other ecological risks following mortality events of dense carp populations are highly likely and include changes in water quality, food webs, consumer populations and the spread of other diseases (Lighten and van Oosterhout 2017; McColl et al. 2017; Paton and McGinness 2018). The severity and duration of these impacts will depend heavily on highly uncertain CyHV-3 disease efficacy, timing, and the mortality rates of carp in a range of environments.

Even a carp mortality rate of only $10-20 \%$, with compounding effects at the landscape scale in warm months, is likely to result in high concentrations of dead carp. Carp carcass decomposition and associated increases in biological oxygen demand from the organic matter and nutrients released in these environments are likely to cause localized hypoxia or anoxia and increases in the prevalence of toxic cyanobacteria blooms. The likelihood and severity of 
Table 1 Ecological safety and efficacy research recommendations to address before releasing CyHV-3 in comparison to research underway by Australia's National Carp Control Plan (NCCP 2017)

\begin{tabular}{|c|c|}
\hline Research recommendations & $\begin{array}{l}\text { Addressed by } \\
\text { NCCP }\end{array}$ \\
\hline $\begin{array}{l}\text { Non-target disease and mortality experiments, including additional experiments on taxa that suffered high (e.g. } \\
>20 \% \text { ) rates of mortality in controls or treatments (Fig. 1). }\end{array}$ & $\begin{array}{l}\text { Partially (see } \\
\text { text) }\end{array}$ \\
\hline Cross-reactivity of $\mathrm{CyHV}-3$ with other viruses and salinities & Yes \\
\hline $\begin{array}{l}\text { Sub-lethal effects of non-target CyHV-3 exposure and additional transmission studies to confirm species- } \\
\text { specificity of asymptomatic carriers and vectors }\end{array}$ & No \\
\hline Test whether CyHV-3 is present in Australian waterways & Proposed \\
\hline Experimental field trials of CyHV-3-induced common carp mortality rates & No \\
\hline $\begin{array}{l}\text { Experimental field and laboratory trials of common carp removal and complementary restoration actions } \\
\text { required for the ecological recovery of Australian biodiversity }\end{array}$ & No \\
\hline Quantify common carp biomass density in Australian waterways & Yes \\
\hline Determine the distribution of genetic $\mathrm{CyHV}-3$ disease resistance in wild common carp & Proposed \\
\hline Epidemiological modelling of disease efficacy and long-term carp population responses & Yes \\
\hline Quantitative food web modelling of the short and long-term impacts of common carp removal & $\begin{array}{l}\text { Partially (see } \\
\text { text) }\end{array}$ \\
\hline Nutrient, cyanobacteria and hypoxia field experiments and modelling of carp decay & Yes \\
\hline Plan for complementary carp biocontrol and restoration activities & No \\
\hline Design fish-kill clean-up and management strategy & Yes \\
\hline
\end{tabular}

these problems increases with warm water temperatures (Kerr et al. 2013, Whitworth and Baldwin, 2016, Whitworth et al. 2012), which are required for CyHV3 disease activity. Eutrophication, deoxygenation, and fish carcasses may promote outbreaks of other diseases (Paton and McGinness 2018). Botulism (Clostridium botulinum) in particular is widespread in wetlands of the MDB (WHA 2013). Warm temperatures, high organic matter concentrations, eutrophication, hypoxia and carcasses promote outbreaks of toxins that can cause botulism (Evelsizer et al. 2010). This disease has led to the deaths of hundreds to thousands of birds and is a risk to other vertebrates (Paton and McGinness 2018), potentially including humans, domestic live-stock and native species. Effects of botulism on fish species in Australia are not well understood, but hypoxia is an increasingly common cause of native fish kills in the MDB (King et al. 2012; Small et al. 2014). Native fishes generally suffer high mortality rates when dissolved oxygen concentrations drop below 2-3 mg/L (Small et al. 2014) and susceptibility is likely to increase with other toxic compounds released from dead carp and high temperatures.
Wetlands, dry-land river waterholes and shallow lake ecosystems will be particularly vulnerable to hypoxia, poor water quality and the ensuing ecological risks resulting from mass, or minor, carp mortality events. These environments with slow or no water current, higher water temperatures and often high densities of carp are likely hot-spots for unwanted ecological change. Physical removal of carp carcasses, following a potential biocontrol release, could mitigate these risks, but we are skeptical that this can be achieved quickly at large spatial scales in complex river-floodplain networks. In the MDB alone, there are approximately 5.7 million hectares of wetlands and 16 Ramsar wetlands of international importance (Pittock and Finlayson 2011) protected under the Australian Environmental Protection and Biodiversity Conservation Act 1999 (EPBC 1999). Warm temperatures, shallow wetlands and high carp densities often coincide with the breeding seasons and sites of a range of fauna (Paton and McGinness 2018). These fauna include threatened waterbirds, fishes, frogs, turtles and mammals protected under the EPBC Act 1999 and are the subjects of significant investments in environmental flows and other conservation management actions. 
Several potential environmental risk modelling approaches are useful to explore the plausible ecological outcomes and uncertainties of releasing CyHV-3 to control carp. First, computational extensions of qualitative modelling based on expert elicitation workshop assessments may be used to translate uncertain interactions of carp removal into quantitative predictive ecosystem ensemble models (Baker et al. 2017). Conceptual ecosystem and food web models are being developed by Australia's National Carp Control Plan and we recommend that these be developed into quantitative assessment tools (Table 1). This approach has offered valuable insight into the unexpected consequences of past non-native species interventions (Raymond et al. 2011) and could be a useful forecasting tool to predict the plausible ecological consequences of carp removal. Lastly, decision theory may be used to distinguish between critical and irrelevant sources of uncertainty and therefore risk, allowing managers to prioritize mitigation activities, and ensure that the chosen actions are robust to limited information (McDonald-Madden et al. 2010).

\section{Is there evidence of $\mathrm{CyHV-3}$ delivering effective control of wild carp populations?}

CyHV-3 has decimated carp farming operations globally (Boutier et al. 2015) but, despite spreading to over 33 countries world-wide, there is little evidence that the virus has suppressed wild populations in lakes, rivers or wetlands. The $50-100 \%$ rates of CyHV-3-induced carp mortality, observed in highdensity aquaculture ponds (Haenen et al. 2004) and optimal laboratory conditions (McColl et al. 2016b), cannot be used to infer biocontrol efficacy in open ecosystems such as rivers, wetlands or lakes. In natural aquatic ecosystems, fish are mobile, have a higher genetic diversity, patchier density, and the environment is more dynamic and heterogeneous (e.g., water temperature) than aquaculture ponds or laboratory conditions. The realized mortality rate of carp, following CyHV-3 biocontrol application in the wild, is likely to be much lower and more variable than in laboratory trials and aquaculture ponds.

Of the few CyHV-3 confirmed carp fish-kills in rivers or lakes world-wide, most have had little or no long-term detectable effect on carp abundance.
Thresher et al. (2018) synthesized and reviewed the available information on CyHV-3-induced carp mortalities in North American lakes. The available information, though coarse grained, suggested that even large and very conspicuous CyHV-3-induced carp mortality events generally had little or no detectable effect on carp abundance (Fig. 2). In fact, carp relative abundance was on average $11.5 \%$ higher after the CyHV-3-induced carp mortality events reviewed by Thresher et al. (2018). Data in Fig. 2 spans as much as 16 years prior to the mortality event (median 6 years), and 7 years afterwards (median 5 years).

There have been only two confirmed instances where CyHV-3-induced mortality rates were high and population suppression may have occurred: Lake Biwa, Japan (Uchii et al. 2013) and Blue Springs Lake in the United States (Thresher et al. 2018). In Lake Biwa, CyHV-3 disproportionately infected and killed approximately $60-80 \%$ of a Japanese strain of common carp (Uchii et al. 2013), while the Eurasian genetic lineages, from which most invasive carp in Australia have descended (Haynes et al. 2009), were

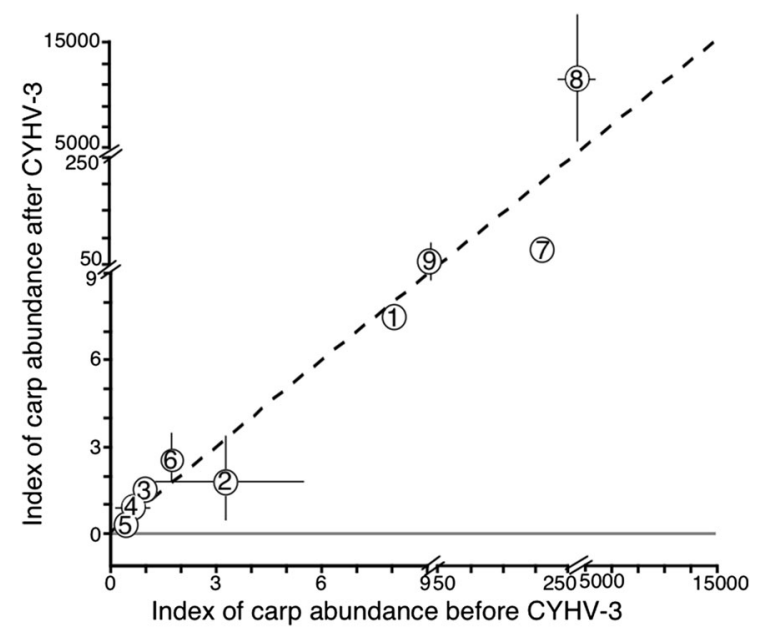

Fig. 2 Indices of common carp relative abundance for individual North American lakes (Thresher et al. 2018) before and after CyHV-3 mortality events. Sampling methods vary among lakes, and include gill netting, trapping, electrofishing and seine netting. Numbers indicate lakes: 1. Twin Buttes Reservoir, Texas; 2. Lake Scugong, Ontario; 3. Rice Lake, Ontario; 4. Buckhorn Lake, Ontario; 5. Balsam Lake, Ontario; 6. Lake Mohave, Nevada; 7. Blue Springs Lake, Missouri; 8. Lake Sinnissipi, Wisconsin; 9. Cheyenne Pond, Nebraska. The dashed line (slope of 1 and an intercept of 0 ) illustrates no change in carp relative abundance. Error bars were calculated as $2 \times \mathrm{SE}$ for lakes where pre- and post-event carp data were available 
largely unaffected. Data on the long-term impacts of mortality on carp abundance in Lake Biwa following the disease outbreak were not available for analysis. In Blue Springs Lake, however, adult abundance and recruitment of carp in the lake has remained low up for up to five years after the 2012 fish-kill event (Thresher et al. 2018). There have been no reports of recurrent CyHV-3 mortality events following the initial outbreak in either lake. We suspect that the high mortality rate of carp in Blue Springs Lake reflects the very small size of the lake, close connectivity of fish and hence the rapid dissemination of the virus throughout the water body, whereas long-term population suppression appears to be maintained by egg predators and piscivorous fish that increased in abundance following the disease out-break (Thresher et al. 2018).

Lake Biwa and Blue Springs Lake are not good models for Australian conditions if the virus was released. Although Lake Biwa is Japan's largest lake, at $670 \mathrm{~km}^{2}$, both it and Blue Springs Lake $\left(3 \mathrm{~km}^{2}\right)$ are dwarfed by the 1 million $\mathrm{km}^{2}$ area of the MDB, let alone the entire continent. Furthermore, the vast network of river channels, warm dry-land floodplains, wetlands and in- and off-channel storages, that comprise the Australian carp distribution, contrasts starkly with the single-lake ecosystems in Japan and the United States. In contrast to lakes, we are aware of no published pre-and-post outbreak evaluation of how CyHV-3 affected carp densities in river ecosystems. CyHV-3 is now present in most rivers in Japan and, despite significant declines in Japanese genetic strains, invasive Eurasian genetic strains have remained widespread and likely carry latent infections (Uchii et al. 2014; Minamoto et al. 2012). Gibson-Reinemer et al. (2017) speculated that a long-term decline in carp abundance throughout the Mississippi River Basin could have been from CyHV-3 disease-induced recruitment failure. They speculate that CyHV-3 was the causative agent, but present no data to establish a causal link. Most of the carp decline reported by Gibson-Reinemer et al. (2017) pre-dates by decades the discovery of CyHV-3 in North America, or the onset of mortality events attributable to the virus. Further research testing whether CyHV-3 is limiting carp recruitment or adult populations in North America is needed.

Mortality events in wild carp populations have been sporadic in time and space, and appear infrequently, or never, after the initial disease outbreak (Uchii et al.
2013; Thresher et al. 2018). Low rates of mortality and once-off outbreaks of disease in wild populations contrast with assumptions made to model potential CyHV-3 impacts on Australian carp. Brown and Gilligan (2014) used a meta-population model of the MDB to predict impacts of CyHV-3 on resident carp populations. They reported that substantial reductions in carp required a minimum of $30 \%$ mortality of the total population every 2-3 years. These assumed parameter values greatly exceed the mortality rates, spatial extent and the frequency of fish-kills, observed in the wild outside of Australia, potentially yielding overly optimistic estimates of the impacts of a carp biocontrol, based on CyHV-3.

Given the high uncertainty in CyHV-3-induced carp mortality rates and frequency of outbreaks in rivers, lakes and wetlands, we recommend that carefully contained field experimental trials be conducted to help refine the wide-ranging estimates (Table 1). Because of the difficulty of containing the virus in natural environments, experiments should first be conducted in quarantined mesocosms or overseas in countries already affected by the virus. Pending the results of experimental field trials, experiments could be scaled up to progressively larger (e.g. $20 \mathrm{~km}^{2}$ ) and more complex natural ecosystems whereby carp and virus density, temperature and interactions with native species could be examined.

Temperature is a key factor influencing carp mortality from CyHV-3 (Minamoto et al. 2012; Marshall et al. 2018). CyHV-3 can cause disease (i.e. clinical signs and mortalities) between the 'permissive' water temperatures of $18-28{ }^{\circ} \mathrm{C}$. Above $30{ }^{\circ} \mathrm{C}$ the virus ceases to replicate and is innocuous to carp. This property has been used to immunize carp against the virus, with temperatures above $30^{\circ} \mathrm{C}$ effectively inhibiting viral replication and allowing the development of a protective adaptive immune response in fish (Ronen et al. 2003). Furthermore, CyHV-3-infected carp can express 'behavioural fever', when they actively seek warm water (Rakus et al. 2017) to stimulate both healing and immunization. In the northern MDB, surface water temperatures in summer can be above $30{ }^{\circ} \mathrm{C}$ for 3-4 months per year, whereas permissive temperatures occur for short periods during spring and autumn (Queensland Government, unpublished data). The thermal profile of river-floodplain ecosystems is also spatially heterogeneous ( $\mathrm{Li}$ et al. 2017), such that the water 
temperature of shallow lakes and wetlands can be over $10{ }^{\circ} \mathrm{C}$ warmer than the connected river channel environment. It seems unlikely that the virus will be an effective biocontrol agent in warm months during the Australian summer, particularly in shallow floodplain environments where carp aggregate in waterholes and wetlands. Virus release during certain seasons or in warm floodplain ecosystems could cause population-level immunization, rather than mass mortality. Given the dispersal capability and behavioural fever expressed by carp, individuals may seekout warm floodplain environments, and we expect immunized individuals to re-colonize regions where the virus was previously effective. Epidemiological modelling currently underway by Australia's National Carp Control Program (Table 1) will address some aspects of these knowledge gaps, but critical uncertainties may remain regarding virus ecology and its interaction with carp behaviour, movement, riverfloodplain flows and temperature.

In other Australian settings, cold-water pollution, downstream of major dams, is likely to provide CyHV-3 disease refuge habitat for carp. Water temperatures downstream of large dams in the MDB are often lower than $15{ }^{\circ} \mathrm{C}$ (Lugg and Copeland 2014), outside the permissive temperature range for $\mathrm{CyHV}-3$ disease (Marshall et al. 2018). Infection with CyHV-3 at low temperature $\left(<15^{\circ} \mathrm{C}\right)$ is incompatible with efficient virus replication and is usually associated with no detectable clinical signs (Sunarto et al. 2014). Compared to warm water temperatures, active immunization at temperatures below $15{ }^{\circ} \mathrm{C}$ is less likely, since the immune response of fish is reduced (Abram et al. 2017). In addition, CyHV-3-infected fish, maintained at low temperatures, frequently develop disease when returned to permissive temperatures (Sunarto et al. 2014). Management options do exist for reducing cold-water pollution (Lugg and Copeland 2014) and should be considered in modelling and prerelease mitigation measures (Table 1) to improve disease efficacy.

In addition to the temperature limitations on biocontrol efficacy, innate genetic resistance of carp to CyHV-3 disease occurs (Rakus et al. 2009; Ito et al. 2014; Piackova et al. 2013). Genetic resistance will be strongly selected for following CyHV-3 release, thereby further reducing the efficacy of biocontrol. Ancestors of CyHV-3 may have infected carp populations, long before the initial outbreaks of the disease were first reported in the late 1990s (Gao et al. 2018). Assuming that the evolutionary rate of CyHV-3 is constant and similar to mammalian alphaherpesviruses, genetic analyses suggest that the virus has co-evolved with carp for tens of thousands of years (Gao et al. 2018). This co-evolution occurred before carp was introduced to Australia in the mid-1800's (Koehn 2004) and even before the species was first cultured by humans (Balon 1995). The exact causes of the recent disease re-emergence are unclear. However, implications of the long co-evolutionary history of CyHV-3 and carp suggests that the virus could already be present in wild Australian populations (Marshall et al. 2018). Japan conducted a nation-wide survey in 2008, which revealed that CyHV-3 had unexpectedly spread to $90 \%$ of rivers tested, without disease outbreaks reported in most rivers (Minamoto et al. 2012). Similar surveys should be conducted in Australia to test for the assumed absence of the virus (Table 1).

Wild carp in Australia are susceptible to CyHV-3 disease (McColl et al. 2016b), but the extent to which genetic variability and resistance-conferring genes (Rakus et al. 2009) will facilitate resistance to the disease remain unknown (Table 1). Reproductively viable hybrids between carp and goldfish (Carassius auratus) occur in Australian wild carp populations (Haynes et al. 2012). Goldfish are resistant to disease caused by CyHV-3 and experimental infections of goldfish $\mathrm{x}$ carp hybrids have revealed moderate-high resistance to CyHV-3 (Hedrick et al. 2006; Bergmann et al. 2010). Hybridization may introduce resistance alleles into carp populations (McColl et al. 2016b), conferring a strong selective advantage to individuals carrying these genes if the virus was introduced. More research is needed to understand the prevalence and spatial distribution of goldfish $\mathrm{x}$ carp hybridization in Australia and resultant resistance to the CyHV-3 (Table 1).

In additional to temperature and genetic constraints on biocontrol efficacy, the extremely high fecundity and short generation time of carp increases the speed at which wild populations are expected to recover. Recovery is likely to occur following large-scale flooding events, which are known to enhance carp recruitment in Australian river-floodplain ecosystems (King et al. 2003; Stuart and Jones 2006; MacDonald and Crook 2014). Effective population control would therefore require the implementation of an effective 
mitigation strategy (Table 1) to limit a recruitment boom of virus-resistant carp in years following release of CyHV-3. This constraint has previously been recognized (McColl et al. 2016a, b), but there is currently no technology or plan in Australia to effectively prevent a recruitment boom of virusresistant carp following a biocontrol release. Other than aligning a potential biocontrol release to coincide with a long-term drought, there is currently no feasible method of preventing or minimising carp recruitment at large spatial scales. Spawning site sabotage, barriers that exclude carp from spawning sites (Weber and Brown 2009; Koehn et al. 2018) and 'Judas-male' approaches (Bajer et al. 2011), though useful in smallscale applications, are unlikely to be effective over large scales in Australia. Similarly, the logistics of increasing the abundance of predatory fish or other taxa that consume carp eggs to the level required for effective population control (Bajer et al. 2012) are daunting.

Thresher et al. (2012, 2014) suggested that CyHV-3 release, followed by stocking large numbers of carp that are both immune to CyHV-3 and produce maleonly offspring ('daughterless technology'), constituted a theoretically feasible option for recruitment suppression. Options for producing daughterless offspring include a Mendelian system (Thresher et al. 2014), chromosomal manipulation (Trojan Y; Teem et al. 2014; Schill et al. 2017), or gene drives (e.g. Beaghton et al. 2016). None of these approaches has been tested in the field. Their genetic feasibility when applied to carp is uncertain and most methods would require substantial lead-in time and logistical effort, even if CyHV-3 was used first to depress carp populations. Gene drives potentially avoid logistical challenges. In theory, even the release of a small number of gene-drive-altered daughterless carp could permanently alter or suppress a targeted population (Esvelt et al. 2014). However, this desirable feature of gene drives also significantly increases the risk to nontarget species (Webber et al. 2015). The ethics and uncertainty associated with gene drives and other genetic biocontrol approaches are currently being debated, with a recommendation that use be highly restricted and not yet applied in widespread biocontrol (National Academies Press 2016; Esvelt and Gemmell 2017).

\section{What are the potential ecological restoration benefits of carp control?}

The goal of Australia's National Carp Control Plan is to "restore native biodiversity". We suggest that this goal is not achievable by carp control alone, and advocate strongly for the implementation of broader ecological restoration principles (Palmer et al. 2005; McDonald et al. 2016). Ecological restoration includes assisting the recovery of a degraded, damaged or destroyed ecosystem. Successful programs include: (1) setting a target for native biodiversity recovery, based on a clearly defined reference site or model of a dynamic and healthy ecosystem; (2) publically available assessments of pre- and postecological condition; (3) improvement in ecological condition and resilience with minimal follow-up maintenance; and (4) causing no lasting harm to the ecosystem (Palmer et al. 2005; McDonald et al. 2016).

There is strong evidence of benefits to biodiversity in freshwater ecosystems, following effective reductions of carp from lakes (Kulhanek et al. 2011; Vilizzi et al. 2015). However, unexpected results are common, and ecological recovery is highly contextdependent, with little data available from river ecosystems (Weber and Brown 2009). There is also little evidence available to evaluate whether CyHV-3 application can facilitate ecological restoration, since the virus has never been intentionally applied as a biocontrol and no field experiments have tested ecological responses (Table 1). With the exceptions of Blue Springs Lake and Lake Biwa (Uchii et al. 2013; Thresher et al. 2018), long-term ecological changes following disease out-breaks have not been documented and remain poorly studied. Carp may increase water turbidity and algal densities (King et al. 1997), decrease benthic algae and macrophyte densities (Robertson et al. 1997; Zambrano and Hinojosa 1999) and negatively affect native fish and benthic invertebrate abundance (Zambrano et al. 2001; Kulhanek et al. 2011; Vilizzi et al. 2015; Kopf et al. 2018). Nevertheless, uncertainty remains about the generality of the impacts of carp across habitats, and especially whether these impacts in river-floodplain ecosystems can be reversed if carp abundance is reduced.

Historical estimates of native species abundance and biomass in Australia are unavailable, but conceptual historical food webs and modelling of biomass can help set recovery baselines for native fish 
communities (Kopf et al. 2018). To help inform native fish restoration targets, an expert panel suggested that native fish abundance in the MDB may have declined by $\sim 90 \%$ since Europeans colonized Australia (Koehn et al. 2014). Effective control of carp and environmental flows in the MDB could more than double native fish biomass, via bottom-up release and production of basal food resources (Kopf et al. 2018). It remains unknown whether there is a threshold density of carp which could promote the recovery of river ecosystems, if this varies among habitats, or if other invasive species (e.g. tench Tinca tinca) would fill the ecological role of carp. We therefore recommend the development of quantitative food web models to better understand the likely responses of native and invasive species (Table 1 ). Where experimental removal has reduced carp densities to less than $100-450 \mathrm{~kg} / \mathrm{ha}$, lakes have been more likely to shift from a turbid eutrophic state to a clearer macrophytedominated state, sometimes with benefits for nutrient cycling and food webs linking plankton, macroinvertebrates and native fish (Zambrano et al. 2001; Weber and Brown 2009). Turbidity, phytoplankton biomass and benthic biofilm development have been significantly altered in Australian floodplain wetlands by manipulating densities of carp ranging from 101 to 1180 kg/ha (King et al. 1997; Robertson et al. 1997).

The biomass density of carp in rivers, lakes and wetlands is heterogeneous and dynamic, commonly ranging from $5 \mathrm{~kg} / \mathrm{ha}$ to over $1000 \mathrm{~kg} / \mathrm{ha}$ (Weber and Brown 2009). Assessments of the density of carp in Australian systems are poor, with current work by Australia's National Carp Control Plan expected to yield more precise estimates (Table 1). Previous estimates from lakes and billabongs range from 150 to $690 \mathrm{~kg} / \mathrm{ha}$ (Fletcher et al. 1985), and $176 \mathrm{~kg} / \mathrm{ha}$ was estimated for the Lachlan River (Brown and Gilligan 2014).

Given the uncertainties in carp reduction necessary to achieve goals of biodiversity recovery in diverse habitats in Australia, we emphasize the need for field experiments and mesocosm studies, which manipulate carp biomass densities, to understand ecosystem responses (Table 1). The estimated carp biomass threshold densities could then serve as quantitative reference targets for comparison with pre-release mortality experiments to determine whether CyHV-3 has the potential to achieve the desired goals.
Complementary restoration and management actions would be essential to achieve ecological restoration targets, including: improving land-use practices to reduce sediment run-off; restoring natural patterns of connectivity; mitigating cold-water pollution from dams; managing environmental flows; complementary carp biocontrol technology to prevent a recruitment boom; and the development of reintroduction and rehabilitation programs for key functional groups (e.g. macrophytes; mussels; predatory fish) (Table 1).

\section{Conclusion}

There is currently insufficient evidence regarding the efficacy, benefits and ecological safety of CyHV-3, to responsibly engage in a continental-scale biocontrol release. Greater understanding of the effectiveness of the virus in Australian rivers and wetlands and the potential ecosystem-level outcomes of suddenly reducing carp biomass densities will be required, even after the completion of Australia's National Carp Control Plan research (Table 1).

The release of a novel virus may unpredictably and irreversibly change ecosystems. Though unexpected outcomes may be unavoidable, rigorously addressing the research gaps and undertaking complementary restoration measures (Table 1) will help reduce uncertainty and maximize potential ecological benefits. Despite the powerful potential of contemporary modelling approaches, our limited knowledge of both CyHV-3 disease efficacy and the response of Australian ecosystems to sudden reductions in carp densities severely restricts our current confidence in assessing ecological responses to biocontrol. Wideranging mortality rates in the wild, poorly described ecological and biological co-factors contributing to CyHV-3 disease out-breaks and the lack of information regarding the biomass density and genetic resistance of carp in Australian waterways (Table 1) contribute to extremely high uncertainty. The current range of plausible ecological risks therefore ranges from little-to-no adverse effects on native species, to catastrophic reductions in water quality that cause severe and widespread fish-kills, potentially with lasting effects on biodiversity. Similarly, the high uncertainty in CyHV-3 efficacy in the wild limits our ability to estimate the likely range of potential benefits 
for native species, which is necessary to rationally justify this biocontrol.

Despite political pressure, there is no environmental justification to rush the release of this viral biocontrol without the necessary evidence. It is important to recognize that the impacts of carp on Australian native biodiversity are relatively static. Carp expanded to their major current range and relative abundance decades ago (Shearer and Mulley 1978; Koehn 2004). Likewise, the potential of CyHV3 to provide a biocontrol solution would not diminish if the research and decision time-frames were extended to reduce key uncertainties and to ensure maximum biocontrol effectiveness.

Acknowledgements Thanks to Matt Barwick formerly of Australia's National Carp Control Plan (NCCP) for comments on a previous version of Table 1. Jon Marshall acknowledges his membership on the Science Advisory Group of the NCCP, representing the Queensland Government.

\section{References}

Abram QH, Dixon B, Katzenback BA (2017) Impacts of low temperature on the teleost immune system. Biology 6(4):39

Bajer PG, Chizinski CJ, Sorensen PW (2011) Using the Judas technique to locate and remove wintertime aggregations of invasive common carp. Fish Manag Ecol 18(6):497-505

Bajer PG, Chizinski CJ, Silbernagel JJ, Sorensen PW (2012) Variation in native micro-predator abundance explains recruitment of a motile invasive fish, the common carp, in a naturally unstable environment. Biol Invasions 14:1919-1929

Baker CM, Gordon A, Bode M (2017) Ensemble ecosystem modelling for predicting ecosystem response to predator reintroduction. Conserv Biol 31(2):376-384

Balon EK (1995) Origin and domestication of the wild carp, Cyprinus carpio: from Roman gourmets to the swimming flowers. Aquaculture 129(1-4):3-48

Beaghton A, Beaghton PJ, Burt A (2016) Gene drive through a landscape: reaction-diffusion models of population suppression and elimination by a sex ratio distorter. Theor Pop Biol 108:51-69

Bergmann SM, Sadowski J, Kielpinski M, Bartlomiejczyk M, Fichtner D, Riebe R, Lenk M, Kempter J (2010) Susceptibility of koi $\mathrm{x}$ crucian carp and koi $\mathrm{x}$ goldfish hybrids to koi herpesvirus (KHV) and the development of KHV disease (KHVD). J Fish Dis 33:267-272

Boutier M, Ronsmans M, Rakus K, Jazowiecka-Rakus J, Vancsok C, Morvan L, Peñaranda MMD, Stone DM, Way K, van Beurden SJ, Davison AJ, Vanderplasschen A (2015) Chapter three-cyprinid herpesvirus 3: an archetype of fish alloherpesviruses. Adv Virus Res 93:161-256

Brown P, Gilligan D (2014) Optimising an integrated pestmanagement strategy for a spatially structured population of common carp (Cyprinus carpio) using meta-population modelling. Mar Freshw Res 65:538-550

Dodd AP (1936) The control and eradication of prickly-pear in Australia. Bull Entomol Res 27(3):503-517

Doherty TS, Ritchie EG (2017) Stop jumping the gun: a call for evidence-based invasive predator management. Conserv Lett 10(1):15-22

Esvelt KM, Gemmell NJ (2017) Conservation demands safe gene drive. PLoS Biol 15(11):e2003850

Esvelt KM, Smidler AL, Catteruccia F, Church GM (2014) Concerning RNA-guided gene drives for the alteration of wild populations. eLife 3:e03401. https://doi.org/10.7554/ elife.03401

Evelsizer DD, Clark RG, Bollinger TK (2010) Relationships between local carcass density and risk of mortality in molting mallards during avian botulism outbreaks. J Wild Dis 46:507-513

Fabian M, Baumer A, Steinhagen D (2013) Do wild fish species contribute to the transmission of koi herpesvirus to carp in hatchery ponds? J Fish Dis 36:505-514

Fabian M, Baumer A, Adamek M, Steinhagen D (2016) Transmission of Cyprinid herpesvirus 3 by wild fish species-results from infection experiments. J Fish Dis 39:625-628

Fletcher AR, Morison AK, Hume DJ (1985) Effects of carp, Cyprinus carpio L., on communities of aquatic vegetation and turbidity of waterbodies in the lower Goulburn River basin. Mar Freshw Res 36(3):311-327

Gaede L, Steinbrück J, Bergmann SM, Jäger K, Gräfe H, Schoon HA, Speck S, Truyen U (2017) Koi herpesvirus infection in experimentally infected common carp Cyprinus carpio (Linnaeus, 1758) and three potential carrier fish species Carassius carassius (Linnaeus, 1758); Rutilus rutilus (Linnaeus, 1758); and Tinca tinca (Linnaeus, 1758) by quantitative real-time PCR and in situ hybridization. J Appl Ichthy 33:776-784

Gao Y, Suárez NM, Wilkie GS, Dong C, Bergmann S, Lee PA, Davison AJ, Vanderplasschen A, Boutier M (2018) Genomic and biologic comparisons of cyprinid herpesvirus 3 strains. Vet Res 49:40

Gibson-Reinemer DK, Chick JH, VanMiddlesworth TD, VanMiddlesworth M, Casper AF (2017) Widespread and enduring demographic collapse of invasive common carp (Cyprinus carpio) in the Upper Mississippi River System. Biol Invasions 19:1905-1916

Gilad O, Yun S, Zagmutt-Vergara FJ, Leutenegger CM, Bercovier H, Hedrick RP (2004) Concentrations of a Koi herpesvirus (KHV) in tissues of experimentally-infected Cyprinus carpio koi as assessed by real-time TaqMan PCR. Dis Aqua Org 60:179-187

Haenen OLM, Way K, Bergmann SM, Ariel E (2004) The emergence of koi herpesvirus and its significance to European aquaculture. Bull Euro Assoc Fish Path 24:293-307

Harris JH, Gehrke PC (1997) Fish and rivers in stress-the NSW rivers survey. NSW Fisheries Office of Conservation \& the Cooperative Research Centre for Freshwater Ecology, Cronulla \& Canberra

Haynes GD, Gilligan DM, Grewe P, Nicholas FW (2009) Population genetics and management units of invasive 
common carp Cyprinus carpio in the Murray-Darling Basin, Australia. J Fish Biol 75(2):295-320

Haynes GD, Gongora J, Gilligan DM, Grewe P, Moran C, Nicholas FW (2012) Cryptic hybridization and introgression between invasive Cyprinid species Cyprinus carpio and $C$ arassius auratus in Australia: implications for invasive species management. Anim Conserv 15(1):83-94

Hedrick RP, Waltzek TB, McDowell TS (2006) Susceptibility of koi carp, common carp, goldfish, and goldfish $\times$ common carp hybrids to cyprinid herpesvirus-2 and herpesvirus-3. J Aquat Anim Health 18:26-34

Hinchliffe C, Atwood T, Ollivier Q, Hammill E (2017) Presence of invasive Gambusia alters ecological communities and the functions they perform in lentic ecosystems. Mar Freshw Res 68(10):1867-1876

Hobbs RJ, Hallett LM, Ehrlich PR, Mooney HA (2011) Intervention ecology: applying ecological science in the twentyfirst century. Bioscience 61(6):442-450

Ilouze M, Davidovich M, Diamant A, Kotler M, Dishon A (2010) The outbreak of carp disease caused by CyHV-3 as a model for new emerging viral diseases in aquaculture: a review. Ecol Res 26:885-892

Ito T, Kurita J, Yuasa K (2014) Differences in the susceptibility of Japanese indigenous and domesticated Eurasian common carp (Cyprinus carpio), identified by mitochondrial DNA typing, to cyprinid herpesvirus 3 (CyHV-3). Vet Microbiol 171:31-40

Kempter J, Kielpinski M, Panicz R, Sadowski J, Myslowski B, Bergmann SM (2012) Horizontal transmission of koi herpes virus (KHV) from potential vector species to common carp. Bull Euro Assoc Fish Path 32:212-219

Kerr JL, Baldwin DS, Whitworth KL (2013) Options for managing hypoxic blackwater events in river systems: a review. J Enviro Man 114:139-147

King AJ, Robertson AI, Healey MR (1997) Experimental manipulations of the biomass of introduced carp (Cyprinus carpio) in billabongs. I. Impacts on water-column properties. Mar Freshw Res 48(5):435-443

King AJ, Humphries P, Lake PS (2003) Fish recruitment on floodplains: the roles of patterns of flooding and life history characteristics. Can J Fish Aqu Sci 60(7):773-786

King AJ, Tonkin Z, Lieshcke J (2012) Short-term effects of a prolonged blackwater event on aquatic fauna in the Murray River, Australia: considerations for future events. Mar Freshw Res 63(7):576-586

Koehn JD (2004) Carp (Cyprinus carpio) as a powerful invader in Australian waterways. Fresh Biol 49(7):882-894

Koehn JD, Lintermans M, Copeland C (2014) Laying the foundations for fish recovery: the first 10 years of the Native Fish Strategy for the Murray-Darling Basin, Australia. Ecol Man Rest 15:3-12

Koehn JD, Todd CR, Zampatti BP, Stuart IG, Conallin A, Thwaites L, Ye Q (2018) Using a population model to inform the management of river flows and invasive carp (Cyprinus carpio). Environ Man 61(3):432-442

Kopf RK, Nimmo DG, Humphries P, Baumgartner LJ, Bode M, Bond NR, Byrom AE, Cucherousset J, Keller RP, King AJ, McGinness HM, Moyle PB, Olden J (2017) Confronting the risks of large-scale invasive species control. Nat Ecol Evol 1:0172
Kopf RK, Humphries P, Bond NR, Sims NC, Watts RJ, Thompson RM, Hladyz S, Koehn JD, King AJ, McCasker N, McDonald S (2018) Macroecology of fish community biomass-size structure: effects of invasive species and river regulation. Can J Fish Aqu Sci. https://doi.org/10.1139/ cjfas-2017-0544

Kulhanek SA, Leung B, Ricciardi A (2011) Using ecological niche models to predict the abundance and impact of invasive species: application to the common carp. Ecol Appl 21(1):203-213

Li Y, Zhang Q, Zhang L, Tan Z, Yao J (2017) Investigation of water temperature variations and sensitivities in a large floodplain lake system (Poyang Lake, China) using a hydrodynamic model. Remote Sens 9(12):1231

Lighten J, van Oosterhout C (2017) Biocontrol of common carp in Australia poses risks to biosecurity. Nat Ecol Evol 1(3):0087

Lowe S, Browne M, Boudjelas S, De Poorter M (2000) 100 of the world's worst invasive alien species: a selection from the global invasive species database. Invasive Species Specialist Group Auckland

Lugg A, Copeland C (2014) Review of cold water pollution in the Murray-Darling Basin and the impacts on fish communities. Ecol Man Rest 15(1):71-79

Macdonald JI, Crook DA (2014) Nursery sources and cohort strength of young-of-the-year common carp (Cyprinus carpio) under differing flow regimes in a regulated floodplain river. Ecol Fresh Fish 23(2):269-282

Marshall J, Davison A, Kopf RK, Boutier M, Stevenson P, Vanderplasschen A (2018) Biocontrol of invasive carp: risks abound. Science 359(6378):877

McColl KA, Sunarto A, Holmes EC (2016a) Cyprinid herpesvirus 3 and its evolutionary future as a biological control agent for carp in Australia. Virol J 13(1):206

McColl KA, Sunarto A, Slater J, Bell K, Asmus M, Fulton W, Hall K, Brown P, Gilligan D, Hoad J (2016b) Cyprinid herpesvirus 3 as a potential biological control agent for carp (Cyprinus carpio) in Australia: susceptibility of nontarget species. J Fish Dis 40(9):1141-1153

McColl KA, Sheppard AW, Barwick M (2017) Safe and effective biocontrol of common carp. Nat Ecol Evol 1:0134

McDonald T, Jonson J, Dixon KW (2016) National standards for the practice of ecological restoration in Australia. Rest Ecol 24:S4-S32

McDonald-Madden E, Probert WJM, Hauser CE, Runge MC, Possingham HP, Jones ME, Moore JL, Rout TM, Vesk PA, Wintle BA (2010) Active adaptive conservation of threatened species in the face of uncertainty. Ecol Appl 20:1476-1489

Minamoto T, Honjo MN, Yamanaka H, Uchii K, Kawabata ZI (2012) Nationwide Cyprinid herpesvirus 3 contamination in natural rivers of Japan. Res Vet Sci 93(1):508-514

National Academies Press (2016) Gene drives on the horizon: advancing science, navigating uncertainty, and aligning research with public values. National Academies Press, Washington

NCCP (2017) The national carp control plan strategic research and technology plan 2017-2019. Fisheries Research and Development Corporation, Australia

OIE (2012) Chapter 2.3.6. Koi herpesvirus disease. In: Manual of diagnostic tests for aquatic animals 2012, pp 328-344 
Palmer MA, Bernhardt ES, Allan JD, Lake PS, Alexander G, Brooks S, Carr J, Clayton S, Dahm CN, Shah JF, Galat DL (2005) Standards for ecologically successful river restoration. J Appl Ecol 42(2):208-217

Paton A, McGinness HM (2018) Food-web effects of sudden changes in fish abundance and mortality: how do fisheaters and other water-dependent fauna respond?. CSIRO, Canberra

Pedler RD, Brandle R, Read JL, Southgate R, Bird P, Moseby KE (2016) Rabbit biocontrol and landscape-scale recovery of threatened desert mammals. Conserv Biol 30(4):774-782

Piackova V, Flajshans M, Pokorova D, Reschova S, Gela D, Cizek A, Vesely T (2013) Sensitivity of common carp, Cyprinus carpio L., strains and crossbreeds reared in the Czech Republic to infection by cyprinid herpesvirus 3 (CyHV-3; KHV). J Fish Dis 36:75-80

Pittock J, Finlayson CM (2011) Australia's Murray Darling Basin: freshwater ecosystem conservation options in an era of climate change. Mar Freshw Res 62:232-243

Pyke GH (2008) Plague minnow or mosquito fish? A review of the biology and impacts of introduced Gambusia species. Ann Rev Ecol Evol Syst 39:171-191

Rakus KL, Wiegertjes GF, Adamek M, Siwicki AK, Lepa A, Irnazarow I (2009) Resistance of common carp (Cyprinus carpio L.) to Cyprinid herpesvirus-3 is influenced by major histocompatibility $(\mathrm{MH})$ class II B gene polymorphism. Fish Shell Immunol 26:737-743

Rakus KL, Ronsmans M, Forlenza M, Boutier M, Piazzon MC, Jazowiecka-Rakus J, Gatherer D, Athanasiadis A, Farnir F, Davison AJ, Boudinot P (2017) Conserved fever pathways across vertebrates: a herpesvirus expressed decoy TNF- $\alpha$ receptor delays behavioral fever in fish. Cell Host Microbe 21:244-253

Raymond B, McInnes J, Dambacher JM, Way S, Bergstrom DM (2011) Qualitative modelling of invasive species eradication on subantarctic Macquarie Island. J Appl Ecol 48:181-191

Robertson AI, Healey MR, King AJ (1997) Experimental manipulations of the biomass of introduced carp (Cyprinus carpio) in billabongs. II. Impacts on benthic properties and processes. Mar Fresh Res 48(5):445-454

Ronen A, Perelberg A, Abramowitz J, Hutoran M, Tinman S, Bejerano I, Steinitz M, Kotler M (2003) Efficient vaccine against the virus causing a lethal disease in cultured Cyprinus carpio. Vaccine 21:4677-4684

Schill DJ, Meyer KA, Hansen MJ (2017) Simulated effects of YY-male stocking and manual suppression for eradicating nonnative brook trout populations. N Am J Fish Manag 37(5):1054-1066

Shearer KD, Mulley JC (1978) The introduction and distribution of the carp, Cyprinus carpio Linnaeus, in Australia. Mar Fresh Res 29:551-563

Shine R (2010) The ecological impact of invasive cane toads (Bufo marinus) in Australia. Q Rev Biol 85(3):253-291

Simberloff D, Stiling P (1996) How risky is biological control. Ecology 77:1965-1974

Simberloff D, Martin J, Genovesi P, Maris V, Wardle DA, Aronson J, Courchamp F, Galil B, García-Berthou E, Pascal M (2013) Impacts of biological invasions: what's what and the way forward. Trends Ecol Evol 28:58-66
Small K, Kopf RK, Watts RJ, Howitt J (2014) Hypoxia, blackwater and fish kills: experimental lethal oxygen thresholds in juvenile predatory lowland river fishes. PLoS ONE 9(4):e94524

Stuart IG, Jones M (2006) Large, regulated forest floodplain is an ideal recruitment zone for non-native common carp (Cyprinus carpio L.). Mar Freshw Res 57(3):333-347

Sunarto A, McColl KA, Crane MS, Schat KA, Slobedman B, Barnes AC, Walker PJ (2014) Characteristics of cyprinid herpesvirus 3 in different phases of infection: implications for disease transmission and control. Virus Res 188:45-53

Teem JL, Gutierrez JB, Parshad RD (2014) A comparison of the Trojan Y Chromosome and daughterless carp eradication strategies. Biol Invasions 16(6):1217-1230

Thresher RE et al (2012) Daughterless technology: a recipe for eradicating carp in Australia. In: Hall HG (ed) Forum abstracts: carp management in Australia. Invasive Animals CRC, Canberra

Thresher RE, van de Kamp J, Campbell G, Canning M, Grewe P, Barney M (2014) Sex-ratio-biasing constructs for the control of invasive lower vertebrates. Nat Biotechnol 32:424-427

Thresher RE, Allman J, Stremick-Thompson L (2018) Impacts of an invasive virus (CyHV-3) on established invasive populations of common carp (Cyprinus carpio) in North America. Biol Invasions 20:1703-1718

Turvey N (2013) Cane toads: a tale of sugar, politics and flawed science. Sydney University Press, Sydney

Uchii K, Okuda N, Minamoto T, Kawabata Z (2013) An emerging infectious pathogen endangers an ancient lineage of common carp by acting synergistically with conspecific exotic strains. Anim Conserv 16:324-330

Uchii K, Minamoto T, Honjo MN, Kawabata Z (2014) Seasonal reactivation enables Cyprinid herpesvirus 3 to persist in a wild host population. FEMS Micrbiol Ecol 87:536-542

Vilizzi L, Tarkan A, Copp G (2015) Experimental evidence from causal criteria analysis for the effects of common carp Cyprinus carpio on freshwater ecosystems: a global perspective. Rev Fish Sci Aqua 23(3):253-290

Webber BL, Raghu S, Edwards OR (2015) Opinion: is CRISPRbased gene drive a biocontrol silver bullet or global conservation threat? Proc Nat Acad Sci 112:10565-10567

Weber MJ, Brown ML (2009) Effects of common carp on aquatic ecosystems 80 years after carp as a dominant: ecological insights for fisheries management. Rev Fish Sci 17(4):524-537

WHA (2013) Botulism in Australian wild birds factsheet. Wildlife Health Australia

Whitworth KL, Baldwin DS (2016) Improving our capacity to manage hypoxic blackwater events in lowland rivers: the Blackwater Risk Assessment Tool. Ecol Model 320:292-298

Whitworth KL, Baldwin DS, Kerr JL (2012) Drought, floods and water quality: drivers of a severe hypoxic blackwater event in a major river system (the southern Murray-Darling Basin, Australia). J Hydrol 450-451:190-198

Zambrano L, Hinojosa D (1999) Direct and indirect effects of carp (Cyprinus carpio L.) on macrophyte and benthic communities in experimental shallow ponds in central Mexico. Hydrobiologia 408:131-138 
R. K. Kopf et al.

Zambrano L, Scheffer M, Martínez-Ramos M (2001) Catastrophic response of lakes to benthivorous fish introduction. Oikos 94(2):344-350

Zavaleta ES, Hobbs RJ, Mooney HA (2001) Viewing invasive species removal in a whole-ecosystem context. Trends Ecol Evol 16(8):454-459
Publisher's Note Springer Nature remains neutral with regard to jurisdictional claims in published maps and institutional affiliations. 